\title{
The Effects of Service Learning and Volunteerism Activities on University Students in Turkey
}

\author{
Nese Boru \\ Correspondence: Nese Boru, Turkey. \\ Received: March 30, 2017 \\ doi:10.11114/jets.v5i6.2405 \\ Accepted: March 24, $2017 \quad$ Online Published: May 7, 2017 \\ URL: https://doi.org/10.11114/jets.v5i6.2405
}

\begin{abstract}
The general purpose of this study is to determine the awareness and acquisitions obtained with service activities by the students studying on undergraduate level in Eskişehir Anadolu University in 2016-2017 education year and involve in service learning and volunteerism activities. The study was designed according to qualitative research method and the case study was used. The data of the study was collected with semi-structured interview technique. Descriptive analysis method was used in analysing the data. Consequently, in this study, 4 main themes, 9 sub-themes and 3 categories were found in accordance with the purpose of the study. Being the first purpose of the study, "the reasons of students' participation into service learning and volunteerism activities" was determined as the first theme of the study. The second purpose, "the effects of service learning and volunteerism activities on students' occupational developments" was determined as the second theme of the study. The third purpose of the study "the effects of service learning and volunteerism activities on students' personal development" was determined as the third theme. The fourth purpose "the effects of service learning and volunteerism activities on students' view about disadvantageous people of the society" was determined as the fourth theme. Sub-themes and categories were classified according to the themes determined.
\end{abstract}

Keywords: higher education, volunteerism, service learning

\section{Introduction}

Human learning occurs in a dynamic framework. This framework consists of personal factors and interaction between environment and behaviours. Personal factors include a person's motivation, self-sufficiency, knowledge, fears and expectations. On the other hand, the environment contains the imposed, the selected and the structured fields (Bandura, 1999; as cited in Meaney, 2012). The imposed field consists of the environments such as school, job and family within which the individuals make interactions every day. The reactions of the individuals against these environments make up the selected field. The structure that the individuals make up by taking what they want from the environment often results in new information, faith and behaviour. The behaviours occurring in the end make up the structured field of the individuals (Meaney, 2012). The process of higher education affects students in the same way. Students enter into higher education with a set of character; however, the environment including the policies of the applications of the institution and the students' experience in higher education continues to influence their character improvement. In the end, students leave from the institutions with re-designed characteristic features (Astin, 1993, p.7; as cited in Mulugetta et al., 1999, p.62). Therefore, higher education programs should be organized in this respect so that students could acquire prosocial behaviours.

Concrete and empirical research activities are needed in order that students get awareness about how they can improve the society and contribute to it (Dewey, 1916; Lake et al., 2015, p.93). In this respect, service-based educational understanding in accordance with Dewey's theory can be seen as an opportunity to improve higher education students' prosocial behaviours.

\section{Service-learning in Higher Education}

Service-learning is based on building cooperation between society and students by bringing the academic studies together with service organizations which serve the society. It is an innovative educational method that ensures students to respond to the needs of the society in environments articulated with real and teaching purposes and within this context it aims to create a strong society by supporting students in exploring themselves and society by using an analytical and profound view to develop their decision-making mechanisms (National Commission on Service-Learning, 2002). Service learning is based on the principle of service philosophy. In this principle, it is aimed that students should 
get experience by building relationship with the organizations that serve for the community and they should learn to take responsibility about the social issues. Service learning is the integration of faculties, students and organizations serving for the community in structured opportunities to meet academic objectives, community needs and intertactions (Flecky, 2010, p.2). In service learning, a connection is established with the members in community organizations through organized projects. Service learning encourages students to make connections between their personal values and academic studies and practise what they have learnt from the real world. It brings an interdisciplinary approach for the adademic studies. It removes the obstacles between higher education and communities (Eyler and Giles, 1999; as cited in Eyler, 2002, pp.517-518).

Service learning is a teaching technique that builds a bridge between academic studies and involving in civil life. This dymanic-pedagogical technique enables students to directly engage in the community service with their own academic outcomes. These educational environments offer students to see the validity of the theorical principles they talk about within the class. These experiences improve students' thinking skills and also enable them to make connections between theory and practise (Cress, 2005; as cited in Meaney,). Students obtain knowledge and skills from the community service experiences. They can present these experiences as new information in class by combining the acquisitions with theory or they can utilize what they have learnt in class environment during the community service. In this respect, students become active learners with service learning (Mitchell, 2008, p.50). The findings obtained from the studies to determine the effects of the understanding of service learning on students are as follows.

According to Winston's study (2015), it was noted that the behaviours of graduate students taking service learning class during higher education, have changed on the issues such as voting for politicians, donating for them, being a member of some organizations that are responsive to the community problems and participating in demonstrations about the unrequired cases by the community. In the study of Crandall \& Zachary (2013), not an important finding was found about whether the students taking service learning classes are open to differences. However, such lessons are still effective in students' obtaining the content of the courses. According to the study Laursen et. al made, the skills about teaching career of graduate students, who took service learning class during higher education was influenced in a positive way. The teachers participating in the study stated that through service learning classes, they were subjected to an interactive and question-based educational approach, therefore, in the lessons they could get some practical skills about teaching career such as course planning, material choice and class management, so that they could start to develop a personal philosophy about teaching style and teaching itself. The participants told that the course content supporting the service learning had positive effects on their personal developments. They expressed that talking about science and managing a class, while they were students, gave a confident feeling as if they were scientists and also helping others gave an internal pleasure.

In Meaney's study (2012), he stated that the participation of P.E teachers into service learning classes influenced on their teaching proficiency positively after graduation. Candidate teachers had a chance to work with the students coming from different races, ethnic groups and economic backgrounds during the process and their perception on low income students and their families were affected. Having such experiences facilitated the candidates' reaction to different cultures after graduation and caused them to develop a faith that all students could succeed by keeping their self-esteem. The teachers who participated and quite experienced in service learning classes at school stated that their education became affected on their teaching experiences in a positive way as long as they practised pedagogical information they learnt at school. Meaney's study showed that the participation into service learning classes at school influenced the teachers' teaching qualification, the acquisition on teaching strategies and the skill to react to other cultures favourably. According to Newman \& Hernandez's (2011) study, the service learning classes have a long lasting and favourable effect on the students' attitudes and behaviours about the career choice, skills development for their career and their participation into service-learning. Besides, these courses not only contribute to students' abilities such as communication, teamwork, leadership, coaching and entrepreneurship significantly, but they also lead the students to increase their social responsibility and show more compassion for needy people.

According to the findings of Sönmez's (2010) study, service learning classes contribute students to acquire a sensitivity to social problems, develop communication skills and build self-confidence. In the study of Çetin \& Sönmez (2009), service-learning classes make a favourable contribution to students' abilities such as social sensitivity, collaboration, cooperation, effective communication, making self-criticism, developing the awareness of social responsibility and getting self-confidence. According to the study of Astin et.al. (2006), the students taking service learning classes during higher education wished to join service-learning after graduation and these students could give more importance to prosocial behaviours such as making donations to charities.

In their study of Fenzel \& Peyrot (2005), it was revealed that service-learning classes have long lasting and favourable effects on students' personal and social development. Service learning classes contribute to students' development of attitudes on the issues such as political participation and serving for community. Within this respect, students take more 
responsibility for social aspects and keep on their participation into service learning after graduation. This situation serves social justice to develop in the community. These effects continue between one year, the least and six years after graduation.

The grad students participating in Kerrigan's (2004) study said that involving in service learning classes during higher education makes easier for them to accept the communities coming from different socio-economical status, ethnic groups, regions and talents. Furthermore, they emphasized that the courses contributed to their career development. They also improved their professional skills such as coordinating long term projects and working in different job fields. The participants stated they continued to work as volunteers after graduation. Only one third of them told that they could improve their ability to cope with community issues about politics. In Kiely's (2004) study, the students taking service learning classes said that they experienced profound and effective changes about their political, ethical, intellectual, personal, spiritual and cultural views. According to the findings in Sedlak's (2003) study, service learning education increases students' self-confidence and self-respects. Service learning classes improve and increase students' social connections. They lay the foundations of the connections of future service learning by enhancing students' feeling to participation into society. Moreover, they strengthen and develop students' writing skills, critical and analytical thinking and questioning abilities.

In the study of Astin et. al. (2000), it was found that students involving in service learning classes at school wish to continue participating in the community service organizations after graduation. It was revealed the courses have positive effects on students' academic skills such as writing and critical thinkinV. They also help students' active participation into organisations, improvement of values such as racial understanding, perception of self-sufficiency, improvement in leadership and capabilities in interpersonal relations and career choice.

\section{Volunteerism in Higher Education}

According to Piaget's cognitive development theory, as they get older, children become more social and their skill to feel empathy for others improves as well. In other words, they learn to see with others' point of views and they start to interiorise others' behaviours and problems (Dovidio et. al., 2006; as cited in Hurvitz, 2010, pp.10-11). People are aroused by the distress of others; this reaction appears even among very young children and occurs across cultures (Eisenberg \& Fabes, 1991; cited in Penner et. al., 2005, p.368). People are motivated to behave in ways that help them attain some goal-improving the person's own situation (egoistic motivation) or, in some cases, improving the welfare of another person (altruistic motivation) (Penner et. al., 2005, p.368). People could participate in activities related to community service voluntarily with seemingly egoistic intentions such as becoming socialize by meeting new people, learning new things, improving personal development (Ryan, Kaplan, \& Grese, 2001), soothing feeling of guilt caused by having more assets than others, finding workmates and joining the occupational groups, engaging in social networks (Drezner, 2011, p.48). The students attending higher education programs could be involved in communities or clubs aiming to serve for community with similar thoughts.

Voluntary works help to strengthen the connections among community members. It also helps to build a bridge between the community and local organizations. It provides a new point of view and employment skills with students and personnel. It supports to increase the life quality in disadvantageous parts in the community (HEACF ${ }^{1} 2005$; as cited in Hall et. al., 2004). It introduces to the students serving for the community with new people and ideas. It makes connections between academic life and community (Boyer, 1987, p.215; as cited in Vernon \& Foster, 2002). The findings obtained from the studies to determine the effect of volunteering works on higher education students are as follow.

According to the findings obtained from 35 undergraduates participating in Sax's (1997, pp.28-29) study titled as 'The benefits of service: Evidence from undergraduates", \%25 of the students who engaged in service learning as undergraduates developed a greater commitment to civic involvement in the years after college. These students became more commitment to some issues such as promoting racial understanding, participating in community action programs, and influencing social values. Besides, it was noticed in this study that the academic success of the students engaging in volunteerism activities when compared with non-participants were higher and they gave more time for studying. According to Sax's story, students' involvement in service works contributes them to understand community problems, know and accept different cultures, learn about human relations, work in a team, and has a positive effect on the issues such as skills in conflict resolution, critical thinking, leadership skills, preparation for careers and self-confidence.

Astin's study (1996) titled as 'Understanding the Effects of Service-Learning in higher education' has favourable results for both the community and students in terms of their critical thinking skills, leadership skills, point of view towards racial understanding, being a volunteer in volunteerism activities after graduation and donating for higher education

${ }^{1}$ Higher Education Active Community Fund 
services after graduation. The only unfavourable outcome for the society in students' volunteerism activities when they are undergraduate is that they feel such weak as to make any change for the society. According to Primavera's study (1999) volunteerism activities contribute to students' knowing themselves and development in academic and social awareness. They improve students in terms of personal developlement and efficacy. They also provide students with improving the awareness about important social issues. They dramatically facilitate the students' acceptance the differences. Furthermore, the students stated in the study that they felt a strong commitment to continue doing some of volunteerism activities in the future.

Volunteerism contributes for an individual to know himself and the society, obtains required social qualifications and provides healthy and effective social relations. However, service learning makes easier for people to notice personal and social problems. It is thought that community service helps social solidarity to make up by allowing people to adopt common universal values such as one's feeling empathy for others, helping needy people and overcoming personal and everyday issues with tolerance and cooperation. It is thought that this study is important because it aims to determine the effects of community service on students' personal, occupational and prosocial behaviours and within this respect the studies made in Turkey are not adequate in quantity.

\section{The Purpose of the Study}

The general purpose of the study is to determine the awareness and the acquisitions of the students who study in Eskişehir Anadolu University and engage in community service activities. According to this general purpose, the sub-purposes of the study are as follows:

1. To determine the reasons of undergraduate students' participation to service learning and volunteerism activities.

2. To find out undergraduate students' opinions about how service learning and volunteerism activities affect their career developments.

a. To determine undergraduate students' opinions about how service learning and volunteerism activities have affected on their information and skills about their learning fields

b. To determine undergraduate students' opinions about how service learning and volunteerism activities affects their career planning.

3. To learn undergraduate students' opinions about how service learning and volunteerism activities have affected on their personal development

a. To determine undergraduate students' opinions about how service learning and volunteerism activities have affected on their personal characteristics.

b. To determine undergraduate students' opinions about how service learning and volunteerism activities have affected on their feelings.

c. To determine undergraduate students' opinions about how service learning and volunteerism activities have affected on their cognitive abilities.

d. To determine undergraduate students' opinions about how service learning and volunteerism activities have affected on their relations with community and their point of view on people.

e. To determine undergraduate students' opinions about how service learning and volunteerism activities have affected on their communication skills.

f. To determine undergraduate students' opinions about how service learning and volunteerism activities have affected on their qualities for leadership and their point of view on leadership.

g. To determine undergraduate students' opinions about how service learning and volunteerism activities have affected on their ability to carry out a project.

4. To determine undergraduate students' opinions about how service learning and volunteerism activities have affected on their point of view on disadvantageous people.

\section{Model of the Study}

The approach of this study was described in qualitative research method. The case study approach, one of the qualitative methods, was used in the study. The data of the study was collected with semi structured interview methods. Descriptive method was used in the analysis of data.

\section{Participants}

The participants of the study consist of undergraduate students studying on undergraduate level in Eskişehir Anadolu University in 2016-2017 education year. Maximum variation sampling, one of the purposed sampling methods was 
utilizied in selection of the students studying on undergraduate level. In order to provide the variety of the participants, it was paid attention that students take service-learning classes and work in community services as volunteers. The range of sex and department variables of the students participating in the study was taken into consideration. Table 1 includes in data of the participants' code, names, sexes, ages, classes, departments and purpose of participation.

Table 1. Demographic Characteristics of the Participants

\begin{tabular}{|c|c|c|c|c|c|}
\hline Code & Sex & Age & Class & Department & Purpose of participation \\
\hline $\mathrm{K} 1$ & Female & 24 & 3 & Undergraduate/Fashion design & Volunteer \\
\hline K2 & Female & 20 & 1 & Undergraduate/Classroom teaching & Volunteer \\
\hline K3 & Female & 21 & 2 & $\begin{array}{c}\text { Undergraduate/Materials science and } \\
\text { engineering }\end{array}$ & Volunteer \\
\hline K4 & Female & 22 & 3 & Undergraduate/Industrial design & Volunteer \\
\hline K5 & Female & 20 & 1 & Undergraduate/ Classroom teaching & Volunteer \\
\hline K6 & Female & 21 & 2 & $\begin{array}{c}\text { Undergraduate/ Speech and language } \\
\text { therapist }\end{array}$ & Volunteer \\
\hline K7 & Male & 21 & 2 & Undergraduate/Labor economics & Volunteer \\
\hline K8 & Male & 20 & 2 & Undergraduate/Finance & Volunteer \\
\hline K9 & Female & 22 & 3 & Undergraduate/Labor economics & Volunteer / Club Director \\
\hline K10 & Male & 23 & 4 & Undergraduate/Labor economics & Volunteer / Club Director \\
\hline K11 & Male & 21 & 2 & Undergraduate/Mental handicap teaching & Volunteer / Club Director \\
\hline K12 & Female & 21 & 3 & Undergraduate/Pharmacy & Volunteer / Club Director \\
\hline K13 & Male & 21 & 3 & Undergraduate/Mental handicap teaching & Mandatory Lesson \\
\hline K14 & Male & 21 & 3 & Undergraduate/Mental handicap teaching & Mandatory Lesson \\
\hline K15 & Male & 21 & 4 & Undergraduate/Mental handicap teaching & Mandatory Lesson \\
\hline K16 & Female & 21 & 4 & Undergraduate/Mental handicap teaching & Mandatory Lesson \\
\hline K17 & Female & 20 & 4 & Undergraduate/Mental handicap teaching & Mandatory Lesson \\
\hline K18 & Female & 21 & 4 & Undergraduate/Mental handicap teaching & Mandatory Lesson \\
\hline K19 & Male & 21 & 2 & $\begin{array}{l}\text { Undergraduate/Physical } \\
\text { teaching }\end{array}$ & Mandatory Lesson \\
\hline K20 & Male & 19 & 2 & $\begin{array}{c}\text { Undergraduate/ } \\
\text { teaching }\end{array}$ & Mandatory Lesson \\
\hline
\end{tabular}

As seen in table 1, the number of the students working as volunteers in community services is 12 , while the number of the students taking service-learning classes is 10 . The number of female students is 11 and male students are 10 . The service learning class the students participated in mandatorily is a teaching practice. This practice aims to gain little vs big fine motor skills, eye-hand-foot coordination to mental handicap individuals with the cooperation of physical education teachers and teachers of mentally handicapped. The undergraduate students engaging voluntarily in community services make some activities such as renewing schools in rural areas, helping organizational structure of school libraries, building shelters for animals, supporting blood donation, holding organizations with lecturers to promote the personal development of undergraduate students, visiting senior centres, the orphans and the inpatients in oncology services.

\section{Data Collection Tools and the Process}

In order to collect data, 'student interview form' prepared by the researcher was used. This interview consists of two parts; demographic characteristics and relevant interview questions. Interview questions were prepared in accordance with the researches that aim to determine the effects of service learning and volunteerism activities on undergraduate students. The questions were sent to the experts to check. After getting feedbacks from the experts, necessary revisions were made. Interview questions consist of 12 open-ended questions in total. Besides, the participants were asked additional questions at the end in accordance with their answers during the interview. The questions having been prepared before were turned into a form in which the study problem and the purpose were stated clearly and it was presented to experts. According to the opinions obtained, necessary corrections were done and a pilot interview with 2 students was conducted in order to test the understandability of the questions. At the end of the study, internal validity of the questions was determined. The interview form is added to the end of the research in Appendix 1.

\section{Data Analysis}

In the analysis of the data obtained at the end of the study, descriptive analysis approach was used. Descriptive analysis approach that is mentioned in Yıldırım \& Şimşek (2006: 224) take in consideration the stages. These are: interview record form: In this stage, the things spoken in the voice records were transferred into the form without making any change. The Interviewers accepted to be interviewed with ethical deal. Producing initial codes and coding: in this stage, interview forms in descriptive data were read and relevant principles were written into the index. Comparing codes and reliability: the number of agreement and disagreement was detected from the markings of researchers and experts. Identifying and commenting the findings: the data processed according to codes were supported with direct quotations 
and these findings were presented. The reliability of the study was calculated using reliability = agreement / (agreement + disagreement) formula. If the reliability calculation is over $\% 81$, this will be an acceptable number for the study (Miles and Huberman, 1994: 64). According to this calculation, the reliability was found to be 0,81 .

\section{Limitations and Weaknesses}

The research's participations were limited with Anatolian University's students. Stundets taking service-learning course were limited with teaching practise.

\section{Findings}

The participants' opinions obtained at the result of the study by analysing the data were classified under 4 themes, 9 sub-themes and 3 categories in the direction of the aims of the study. During the classification, the frequency distribution of the opinions was taken into consideration and they were shaped as tables. The direct quotations which were regarded as remarkable by the researcher were included below the tables. The frequency distribution of the undergraduate students working voluntarily for community services was ranked as "V" column, while the frequency distribution taking service learning classes was ranked as "S.L." column. The column in the table with the name of "T" gives the total distribution of frequencies of the relevant opinion. In the presentation of the findings, the principle of internal validity was taken in account and the order stated in the purposes was followed.

\subsection{The Reasons for Students' Participation in Service Learning and Volunteerism Activities}

In accordance with the first purpose of the study, "the reasons for students' participation into service learning activities" was determined as the first theme of the study. The participants' opinions about the first theme of the study are given in table 2. As can be seen in Table 2, 11 of the undergraduate students incorporating in the study said "I take service learning classes", 6 of them stated "I took part in because I wanted to help people" and 2 of them said "I was involved because I wanted to make friends and get socialize". The quotations about some of these opinions were given under the table.

Table 2. The reasons for students' participation in service learning and volunteerism activities

\begin{tabular}{|c|c|c|c|}
\hline \multirow{2}{*}{ The reasons for students' participation in service learning and volunteerism activities } & \multicolumn{3}{|l|}{$\mathbf{f}$} \\
\hline & V. & S.L. & $\mathrm{T}$ \\
\hline I have to take service learning classes & - & 11 & 11 \\
\hline I took part in because I wanted to help people & 6 & - & 6 \\
\hline I was involved because I wanted to make friends and get socialize & 2 & - & 2 \\
\hline I joined because I was in search for something. & 1 & - & 1 \\
\hline I joined because I wanted to become active & 1 & - & 1 \\
\hline I joined because I wanted to improve myself personally & 1 & - & 1 \\
\hline I joined because I myself feel responsible to the society. & 1 & - & 1 \\
\hline I joined because I needed to deal with something. & 1 & - & 1 \\
\hline I joined because I wanted to get spiritual satisfaction without any financial worry & 1 & - & 1 \\
\hline Since I wanted to give my clothes, I looked for a club. & 1 & - & 1 \\
\hline I joined because I learnt to help people from my family. & 1 & - & 1 \\
\hline
\end{tabular}

About the opinion, "I was involved because I wanted to make friends and get socialize" which is under the main theme of the reasons for students' participation in service learning and volunteerism activities students', K9 said: "to make friends in a society is very important for a student notably for a student of faculty of economics and administrative sciences, we call this as human capital. ... however many people you know, do these with help or without help. Apart from moral value, I think this will help our future business life in a significant way... For instance, well, when you individually help a person in a foundation, establishment or in a club, its moral aspect influences you very much. Talking about this or not is something different, but in an interview or in a dialogue with someone, when you are asked what you have done, the question what you have added values to people is particularly asked. I think it has an important place in this point... When we provide these kind of assists, there are many institutions we are talkinV. We need to found a company, we need to take people's attraction, we help people through these ... While we make collaboration with outside, the environment ... we not only introduce ourselves but also .... It has a significant effect in business life."

\subsection{The Effects of Service Learning and Volunteerism Activities on Career Development of the Students}

In accordance with the second purpose of the study, "The effects of service learning and volunteerism activities on career development of the students" was determined as the second theme of the study. Under the second theme of the study, 2 sub-themes and 3 categories were determined.

The effects of service learning and volunteerism activities on the students' knowledge and skills about their learning fields 
The participants' opinions about the sub-theme, "The effects of service learning activities on the students' knowledge and skills about their learning fields", which belongs to the second main theme of the study, are given in table 3 . The relevant opinions were divided into 3 categories as acquisitions and awareness about all of the departments, acquisitions and awareness about teaching profession and acquisitions and awareness about other departments. As seen in Table 3, 8 of the undergraduate students incorporated in the study stated that "I gained positive experiences about teaching profession", 6 of them said "I experienced the knowledge I learnt in theory", 4 of them said "My department is mental handicapped teaching, I noticed the importance of having relations with colleagues of all branches" and 4 of them said "My department is mental handicapped teaching, service learning class was not sufficiently functional for teaching experience". The quotations about some of these opinions were given under the table.

Table 3. The effects of service learning and volunteerism activities on the students' knowledge and skills about their learning fields

\begin{tabular}{|c|c|c|c|}
\hline $\begin{array}{l}\text { The effects of service learning and volunteerism activities on the students' knowledge } \\
\text { and skills about their learning fields }\end{array}$ & $\mathbf{f}$ & & \\
\hline Acquisitions and awareness about all of the departments & V. & S.L. & $\mathrm{T}$ \\
\hline I experienced the knowledge I learnt in theory & 2 & 4 & 6 \\
\hline I noticed learning by experience is more effective that learning by reading & 2 & - & 2 \\
\hline Acquisitions and awareness about teaching profession & V. & S.L. & $\mathrm{T}$ \\
\hline I gained positive experiences about teaching profession. & 2 & 6 & 8 \\
\hline $\begin{array}{l}\text { My department is mental handicapped teaching, I noticed the importance of having relations } \\
\text { with colleagues of all branches }\end{array}$ & - & 4 & 4 \\
\hline $\begin{array}{l}\text { My department is mental handicapped teaching, service learning class was not sufficiently } \\
\text { functional for teaching experience }\end{array}$ & - & 4 & 4 \\
\hline $\begin{array}{l}\text { My department is mental handicapped teaching, service learning class was not functional for } \\
\text { the development of students }\end{array}$ & - & 4 & 4 \\
\hline $\begin{array}{l}\text { My department is mental handicapped teaching, the time planning of service learning class } \\
\text { was not appropriate. }\end{array}$ & - & 2 & 2 \\
\hline $\begin{array}{l}\text { My department is faculty of physical education and sport, I noticed I should be quick, } \\
\text { practical and careful while working with mentally handicapped students }\end{array}$ & - & 2 & 2 \\
\hline $\begin{array}{l}\text { My department is mental handicapped teaching, I witnessed that some parents were } \\
\text { indifferent to their students. }\end{array}$ & - & 2 & 2 \\
\hline $\begin{array}{l}\text { My department is mental handicapped teaching, I saw some of my colleagues are weaker in } \\
\text { a humanistic manner. }\end{array}$ & - & 2 & 2 \\
\hline $\begin{array}{l}\text { My department is faculty of physical education and sport, I understood if I could teach } \\
\text { autistic children, I could teach other children more easily }\end{array}$ & - & 1 & 1 \\
\hline $\begin{array}{l}\text { My department is mental handicapped teaching, I saw some of my colleagues couldn't } \\
\text { control over their students. }\end{array}$ & - & 1 & 1 \\
\hline $\begin{array}{l}\text { My department is mental handicapped teaching, I saw some of the parents were } \\
\text { oversensitive to their students }\end{array}$ & - & 1 & 1 \\
\hline $\begin{array}{l}\text { My department is mental handicapped teaching, I noticed that sportive activities are } \\
\text { important for the students with mental disabilities. }\end{array}$ & - & 1 & 1 \\
\hline $\begin{array}{l}\text { My department is mental handicapped teaching, I noticed the difficulties of the } \\
\text { responsibilities of mental handicapped teaching }\end{array}$ & - & 1 & 1 \\
\hline Acquisitions and awareness about other departments & V. & S.L. & $\mathrm{T}$ \\
\hline My department is engineering, I started to become more successful in lesson presentations. & 1 & - & 1 \\
\hline My department is pharmacy, I noticed that I could take part in chambers of pharmacists. & 1 & - & 1 \\
\hline $\begin{array}{l}\text { My department is language therapist, I think I can advance my improvement positively on } \\
\text { the field I have learnt }\end{array}$ & 1 & - & 1 \\
\hline $\begin{array}{l}\text { My department is the economics and administrative sciences, I think my chance to find a job } \\
\text { on the field I have learnt is influenced positively. }\end{array}$ & 1 & - & 1 \\
\hline My department is Finance, I learned institution management & 1 & - & 1 \\
\hline
\end{tabular}

K16 stated her opinion about "My department is mental handicapped teaching, service learning class was not sufficiently functional for teaching experience" which is the sub-theme of "The effects of service learning and volunteerism activities on the students' knowledge and skills about their learning fields" as such: "If the lesson were not mandatory, we could study more effectively in the hour or time we chose. What were we doing, we were going out of the lesson, last term we were too busy, we were always making presentations, lots of materials, then going out of the lesson, with tiredness, well there we tried to be beneficial to children, were going out like a little bit feeling a wreck, it was unproductive ... if the lesson were performance-based and mandatory, your performance drops to minimum like this, it doesn't work, because there is an interactivity, also there you gain nothing, when I go there, I want to be beneficial to the child indeed, I want to see something, another way to say, ...,for example, when we went there, we could work with the same child, to see his progress, it was some mandatory for us, you know the children were being distributed randomly, there was no plan or a schedule,... this gave nothing to me,... this gave nothing to children either... while making sport, I teach the child to make it with order and I teach them to get in line, I worked on it, on the day the 
children worked with me, they were getting in line, yet one day later, they were working with different teacher with different style and they didn't care the line and breaking the queue up... there, I was thinking we went there to save the day, which was what happened, I for instance, passed with AA and yes I won ... it happened and finished but..."

\section{The effects of service learning and volunteerism activities on students'career plans}

The participants' opinions about the sub-themes of the second theme of the study "The effects of service learning activities on students' career plans" are given in table 4. As can be seen in Table 4, 3 of undergraduate students said "I noticed myself to be a director or something" and 2 of them said "I saw these activities made a difference in my CV" and one of them said "I started to think that I can build my own business". The quotations about some of these opinions were given under the table.

Table 4. The effects of service learning and volunteerism activities on students' career plans

\begin{tabular}{|c|c|c|c|}
\hline The effects of service learning and volunteerism activities on students' career plans & f & & \\
\hline & $\mathrm{V}$. & S.L. & $\mathrm{T}$ \\
\hline I noticed myself to be a director or something. & 3 & - & 3 \\
\hline I understood that I can make mental handicapped teaching & - & 3 & 3 \\
\hline I saw these activities made a difference in my $\mathrm{CV}$. & 2 & - & 2 \\
\hline I started to think that I can build my own business & 1 & - & 1 \\
\hline I noticed that I didn't want to be an officer and that I didn't like monoto & 1 & - & 1 \\
\hline I noticed that I wanted to work in the fields such as trading or politics. & 1 & - & 1 \\
\hline My prejudice about teaching profession was broken down, I noticed that I could be a teacher. & 1 & - & 1 \\
\hline I started to think working in a school with autistic children & - & 1 & 1 \\
\hline I started to think studying about autistic children in my post-graduate education. & - & 1 & 1 \\
\hline $\begin{array}{l}\text { I chose healthcare management as the field in evening education in accordance with the studies I made with } \\
\text { LÖ-SEV }{ }^{2} \text {. }\end{array}$ & 1 & - & 1 \\
\hline I started to think that I could use philosophy in my industrial design works. & 1 & - & 1 \\
\hline I learnt people should do their job voluntarily and fondly & 1 & - & 1 \\
\hline I understood the importance to know a foreign language & 1 & - & 1 \\
\hline I noticed that people should have some qualification and expertness fields & 1 & - & 1 \\
\hline
\end{tabular}

K12 stated about the sub-themes 'I started to think that I can build my own business' and 'I noticed myself to be a director or something' which belongs to second theme of the study 'The effects of service learning and volunteerism activities on students' career plans' as such: "I was thinking to open a pharmacy before, but now in a company as a director, that is, ... I want to work in a firm in healthcare sector and then I want to build my own business, my own company... this may be a big dream, I think people should have big dreams... even I think if I built my own business, who would I choose to work with, with each person I meet, I am thinking this.".

\subsection{The Effects of Service Learning and Volunteerism Activities on Students'Personal Development}

"The effects of service learning and volunteerism activities on students' personal development" was determined as the third main theme of the study. 7 sub-themes were determined under the third main theme.

\section{The effects of service learning and volunteerism activities on students' personal characteristics}

The participants' opinions about the sub-theme "The effects of service learning activities on students' personal characteristics" which belongs to the third main theme are given in table 4. As can be seen in Table 5, 9 of undergraduate students incorporated in the study said "my self-confidence increased", 6 of them said "My joy of living increased and 5 of them said "I learnt not to give up". The quotations about some of these opinions were given under the table.

\footnotetext{
${ }^{2}$ Foundation for Children with Leukemia
} 
Table 5. The effects of service learning and volunteerism activities on students' personal characteristics

\begin{tabular}{|c|c|c|c|}
\hline \multirow{2}{*}{ The effects of service learning and volunteerism activities on students' personal characteristics } & \multicolumn{3}{|l|}{ f } \\
\hline & $\mathrm{V}$. & S.L. & $\mathrm{T}$ \\
\hline My self-confidence increased & 5 & 4 & 9 \\
\hline My joy of living increased & 6 & - & 6 \\
\hline I learnt not to give up & 4 & 1 & 5 \\
\hline My empathy increased & 4 & - & 4 \\
\hline I became a more blessing person & 4 & - & 4 \\
\hline I became a more responsible person & 2 & 2 & 4 \\
\hline I became a more hardworking person & 2 & 2 & 4 \\
\hline I knew more about myself & 4 & - & 4 \\
\hline I became a more patient person & 2 & 1 & 3 \\
\hline I noticed that I should control my anger & 3 & - & 3 \\
\hline I became a more outgoing person & 2 & - & 2 \\
\hline I became a more self-sacrificing person & 2 & - & 2 \\
\hline I managed to stop being selfish & 2 & - & 2 \\
\hline I learnt to say unless something happens, there must be a reason & 2 & - & 2 \\
\hline I noticed that sometimes I should say no and I shouldn't feel pity & 1 & 1 & 2 \\
\hline I became a more mature person & 1 & 1 & 2 \\
\hline My shyness disappeared & 1 & - & 1 \\
\hline I felt I am useful & - & 1 & 1 \\
\hline I felt myself respected & - & 1 & 1 \\
\hline I felt proud of myself & - & 1 & 1 \\
\hline I became a stronger person & - & 1 & 1 \\
\hline I noticed I should be more free & - & 1 & 1 \\
\hline I became a more helpful person & - & 1 & 1 \\
\hline I became a more planned person & 1 & - & 1 \\
\hline I became a more smiling person & 1 & - & 1 \\
\hline I became a more ambitious person & 1 & - & 1 \\
\hline I became a more searching person & 1 & - & 1 \\
\hline I became a more sharing person & 1 & - & 1 \\
\hline I became a more logical person & 1 & - & 1 \\
\hline I learnt how to control my anger & 1 & - & 1 \\
\hline My ability to observe people increased & 1 & - & 1 \\
\hline I became a more experienced person against life & 1 & - & 1 \\
\hline I became a more striving person rather than acting high-handedly & 1 & - & 1 \\
\hline I noticed I am a patient person & 1 & - & 1 \\
\hline I improved my auto-control & 1 & - & 1 \\
\hline I noticed I shouldn't behave capriciously unnecessarily & 1 & - & 1 \\
\hline I learnt not to care of little things & 1 & - & 1 \\
\hline I noticed that some of our wishes are childish & 1 & - & 1 \\
\hline I learnt to defy and struggle against negativities & 1 & - & 1 \\
\hline
\end{tabular}

K12 stated his opinion about "My joy of living increased" included in the sub-theme "The effects of service learning and volunteerism activities on students' personal characteristics", as such: "We went to Günyüzü town. There were children an parents in Günyüzü who didn't or couldn't go out from the town... What I learnt from them was that they somehow managed to hold on to life so well that they hadn't ever lost their pleasure of life ... people have been living something, none of them is where they want to be, none of them could do what they want. When we speak with the females, they have actually some degree of sadness in their eyes, but they have found a way to hold on to life anyway. I concluded for myself that I sometimes go through unhappy periods ... sometimes our motivation decreases without any apparent reason, but they somehow managed to enjoy themselves and to keep on with joy, if they could manage, of course all of us could do it because we are free to do what we want or to be where we want... I think I was able to learn this fact from those people.".

\section{The effects of service learning and volunteerism activities on students' emotions}

The participants' opinions about the sub-theme "The effects of service learning activities on students' emotions" are given in Table 6. As seen in Table 6, 12 of the undergraduate students said "I became happy" and 4 of them said "I became a more emotional person". The quotations about some of these opinions were given under the table. 
Table 6. The effects of service learning and volunteerism activities on students'emotions

\begin{tabular}{llll}
\hline The effects of service learning and volunteerism activities on students'emotions & f & \\
\hline & V. & S.L. & T \\
\hline I became happy & 6 & 6 & 12 \\
I became more emotional person & 3 & 1 & 4 \\
I became more peaceful person & 1 & 1 & 2 \\
I became more sensitive person & 1 & 1 & 2 \\
I felt that my conscious is clear & 1 & 1 & 2 \\
I noticed that my love increased towards mentally handicapped students & - & 2 & 2 \\
I improved my spiritual wellness & - & 1 & 1 \\
I felt spiritual satisfaction & 1 & - & 1 \\
I felt my sense of motherhood & 1 & - & 1 \\
I improved in loving & 1 & - & 1 \\
I realized that materiality is nothing compared with spirituality & 1 & - & 1 \\
I experienced the feeling of being loved & 1 & - & 1 \\
\hline
\end{tabular}

K9 told his opinion about the statement "I became more emotional person", which belongs to the sub-theme, "The effects of service learning and volunteerism activities on students'emotions", as such: “...sometimes I am a hard person, I was once such person against people. ... there is a definition, sometimes causing me called as cruel, and sometimes, how I say, a little bit insensitive person, about me there was something presented like character, this is not a thing that I exactly believe, I speak with people's point of view now, I was once said as a comment about my personality that how cruel I was and now I am thinking about the point that I come to, I believe every one of the people has frailties and weakness and I have passed this by helping people. For instance, this contributed me to be calmer and an ability to understand people... For example, in the past I used to think about others' problems like 'really, is it so? Never mind, I don't care, what can we do, this is her/his fate...now, how can we help him/her, what can we do, let's think about it together... for me it has made a contribution like this. Others' problems have become my problems... this is the biggest contirubution to me."

\section{The effects of service learning and volunteerism activities on students' cognitive skills}

The participants' opinions about the sub-theme 'The effects of service learning activities on students' cognitive skills', which belongs to the second theme of the study, are given in table 7. As seen in Table 7, of the undergraduate students participating in the study, 10 said "My ability to solve problems improved", 5 said "My ability to think in multiple ways improved", 4 said "My ability to think creatively improved" and 2 said "My ability to practise the decisions I made improved". The quotations about some of these opinions were given under the table.

Table 7. The effects of service learning and volunteerism activities on students' cognitive skill

\begin{tabular}{|c|c|c|c|}
\hline Topluma hizmet çalışmalarının öğrencilerin zihinsel becerileri üzerindeki etkileri & f & & \\
\hline & G. & T.H. & $\mathrm{T}$ \\
\hline My ability to solve problems improved & 3 & 7 & 10 \\
\hline My ability to think in multiple ways improved & 3 & 2 & 5 \\
\hline My ability to think creatively imroved & 1 & 3 & 4 \\
\hline My ability to think strategically imroved & 1 & 3 & 4 \\
\hline My ability to practise the decisions I made improved & 1 & 1 & 2 \\
\hline My ability to think critically improved & - & 2 & 2 \\
\hline I learnt to decide quicker & - & 1 & 1 \\
\hline I learnt not to engage my mind with irrelevant things & - & 1 & 1 \\
\hline
\end{tabular}

K4 stated her opinion about the sub-theme "My ability to think in multiple ways improved", which belongs to the main theme of "The effects of service learning and volunteerism activities on students' cognitive skills" as such: "...actually I learnt some about multiple thinking... for example, it is some dominated in our society, we learn as if there was only one answer of the things, actually the department I study is also effective, since I study Design, actually even also at school, I try to think differently but now thinking differently but actually by taking the right step, I think we're also doing like this: making something voluntarily means taking the right step, I mean not looking from the only one direction when something happens, but how can it be, but how does it seem from this direction, that is, we can produce anything just by looking from different aspects, directions, and if we could see the aspects, then it would be really beneficial for all of us..."

The effects of service learning and volunteerism activities on students' relations with community and their point of view against people

The participants' opinions about the theme "The effects of service learning activities on students' relations with community and their point of view against people are given in table 8 . As seen in Table 8 , of the undergraduate students, 5 said "My prejudices were broken down", 3 students said "I became a more tolerant person" 3 students stated "I learnt to accept everyone as what they are" and 1 said "I noticed that we shouldn't lacerate each other just because of small 
problems". The quotations about some of these opinions were given under the table.

\begin{tabular}{|c|c|c|c|}
\hline \multicolumn{4}{|c|}{$\begin{array}{l}\text { The effects of service learning and volunteerism activities on students' relations with } \\
\text { community and their point of view against people }\end{array}$} \\
\hline & V. & S.L. & $\mathrm{T}$ \\
\hline My social background expanded & 5 & 1 & 6 \\
\hline My prejudices were broken down & 5 & - & 5 \\
\hline I became a more tolerant person & 3 & - & 3 \\
\hline I learnt to accept everyone as what they are & 3 & - & 3 \\
\hline I had a chance to know the people who had similar thoughts of mine & 3 & - & 3 \\
\hline I noticed that the more people I deal with the more I learn & 2 & - & 2 \\
\hline I saw that I could learn something from everyone & 2 & - & 2 \\
\hline I noticed that all of us need love & 1 & - & 1 \\
\hline I noticed that I should behave people respectfully & - & 1 & 1 \\
\hline I improved in knowing people & 1 & - & 1 \\
\hline I noticed the importance to be respectful to people's ideas & 1 & - & 1 \\
\hline I noticed that people might not be perfect, and they can make mistakes & 1 & - & 1 \\
\hline I noticed the importance of friendship & 1 & - & 1 \\
\hline I noticed that we shouldn't lacerate each other just because of small problems & 1 & - & 1 \\
\hline The meaning I ascribed to friendship changed & 1 & - & 1 \\
\hline My taboos were broken & 1 & - & 1 \\
\hline I saw how much people could be self-sacrificing & 1 & - & 1 \\
\hline I had a chance to know people with different characters & 1 & - & 1 \\
\hline I started to avoid the jokes which hurt my friends & 1 & - & 1 \\
\hline I noticed that anyone can do any job & 1 & - & 1 \\
\hline I saw that in a non-profit organation, you can produce works with any kind of person & 1 & - & 1 \\
\hline I began to see people more positively & 1 & - & 1 \\
\hline
\end{tabular}

Table 8. The effects of service learning and volunteerism activities on students' relations with community and their point of view against people.

K12 stated her opinions about the statements "I became a more tolerant person" and "I learnt to accept everyone as what they are" which are the sub-theme of "The effects of service learning and volunteerism activities on students" relations with community and their point of view against people", as such: “... when I was the director, it was not possible to understand everyone at the same way, to respond them at the same time and to give feedback to all of them, but I noticed that I was expecting people to do all of these, I mean I was thinking of everyone at the same level, yet it shouldn't be so, everyone has some capabilities in different fields and some inabilities as well. We all have some deficiencies. I noticed that I was inconsiderate, let's not say despising, but not considerate enough on the issue. But now, at this point I think I can accept everyone as what they are and I can see the positive and negative sides of everyone more clearly."

\section{The effects of service learning and volunteerism activities on students' communication skills}

The participants' opinions about the sub-theme "The effects of service learning activities on students' communication skills" are given in Table 9. As seen in table 9, of the undergraduate students, 4 said "I noticed that I should care with whom and how I should communicate", 2 students said "I noticed the importance of being a good listener in communication" and 1 said "I noticed that I shouldn't have a big mouth in communication". The quotations about some of these opinions were given under the table. 
Table 9. The effects of service learning and volunteerism activities on students' communication skills

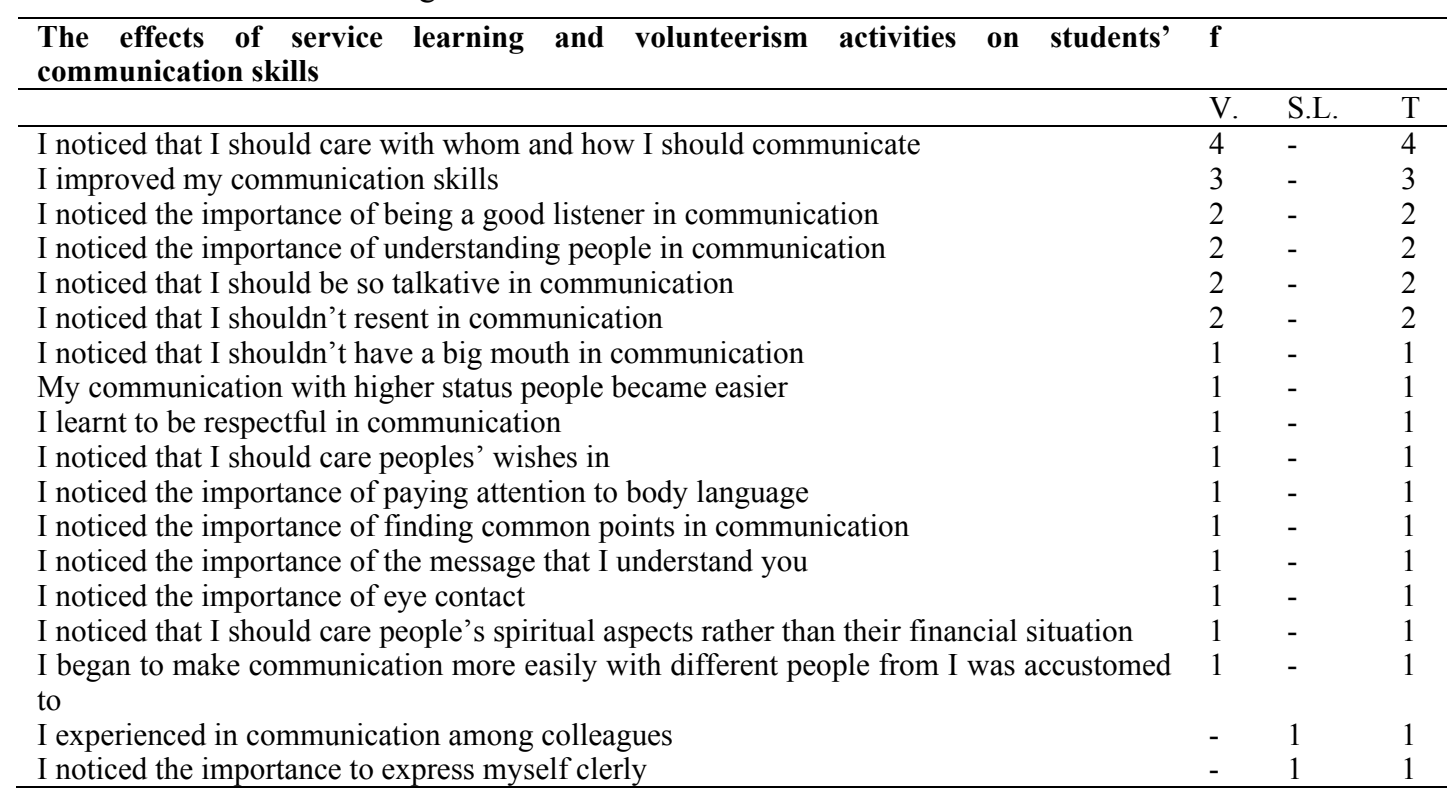

K11 stated his opinions about "I noticed that I should care with whom and how I should communicate" which is under the sub-theme of "The effects of service learning and volunteerism activities on students' communication skills" as such: "There are some differences in styles and there are some problems in connection ... In communication, sometimes it is necessary to say beautiful apple instead of apple is beautiful... I don't necessarily approve that but I noticed that it is necessary to use a different language from post to post. For example, one regulates his speaking style accordingly, there are some factors in which you should be formal in formal places and informal in informal places and sometimes you should be formal with informal places as there may be a different person in the place."

The effects of service learning and volunteerism activities on students' skills for leadership and their point of view on leadership

The participants' opinions about the title "The effects of service learning activities on students' skills for leadership and their point of view on leadership" which belongs to the third main theme are given in Table 10. As seen in table 10, of the undergraduate students participating in the study, 5 said "I learnt that leadership is directing people without dominating over", 4 said "I noticed the importance of being open-minded instead of saying "I know", and one said "I learnt that winning people depends on little details". The quotations about some of these opinions were given under the table. 
Table 10. The effects of service learning and volunteerism activities on students' skills for leadership and their point of view on leadership

\begin{tabular}{|c|c|c|c|}
\hline & V. & S.L. & $\mathrm{T}$ \\
\hline I learnt that leadership is directing people without dominating over & 4 & 1 & 5 \\
\hline I noticed the importance of being open-minded instead of saying "I know" & 4 & - & 4 \\
\hline I learnt that leadership is to manage people & 3 & - & 3 \\
\hline I learnt that leadership is to give the job to the capable one in the distribution of work & 3 & - & 3 \\
\hline I noticed that my ability to convince improved & 2 & - & 2 \\
\hline I learnt that leadership is to be fair & 2 & - & 2 \\
\hline I learnt that leadership is to be creative & 2 & - & 2 \\
\hline I learnt that leadership is to decide calmly during crisis & 2 & - & 2 \\
\hline I learnt that the aim of leadership is to win friends & 1 & - & 1 \\
\hline I learnt that winning people's trust depends on little details & 1 & - & 1 \\
\hline I learnt that leadership is to keep a foot in all people's camps without cheating them & 1 & - & 1 \\
\hline I noticed that skill and thinking ability is needed for leadership & 1 & - & 1 \\
\hline I learnt about the crisis management & 1 & - & 1 \\
\hline I learnt that leadershio is to share the responsibilities & 1 & - & 1 \\
\hline I learnt that leadership is to be clear in work distribution & 1 & - & 1 \\
\hline I learnt that leadership is to explore the positive sides of people & 1 & - & 1 \\
\hline I learnt that leadership is to try to correct negative sides of people without being offensive & 1 & - & 1 \\
\hline I learnt that leadership is to activate people by giving them confidence & 1 & - & 1 \\
\hline I learnt that leadership is to take all respobsibilities & 1 & - & 1 \\
\hline I learnt that leadership is to fix something & 1 & - & 1 \\
\hline I learnt that leadership is to motivate people who become pessimistic during a crisis & 1 & - & 1 \\
\hline I learnt that leadership is to create an identity of "we" & 1 & - & 1 \\
\hline I learnt that leadership is to make people believe to himself & 1 & - & 1 \\
\hline I learnt that leadership is to be the loved one unlike mostly unloved administration & 1 & - & 1 \\
\hline I learnt that leadership is sincerity & 1 & - & 1 \\
\hline I learnt that leadership is to help followers about how a work is done & 1 & - & 1 \\
\hline I learnt that leadership is not to deviate from the main purpose readily & 1 & - & 1 \\
\hline I learnt that leadership is to have alternative plans & 1 & - & 1 \\
\hline I learnt that leadership is responsibility & 1 & - & 1 \\
\hline I learnt that leadership is to develop not to make no progress & 1 & - & 1 \\
\hline I learnt that leadership means producing something & 1 & - & 1 \\
\hline I learnt that leadership means achievement & 1 & - & 1 \\
\hline I learnt that leadership is to make lots of mental activities & 1 & - & 1 \\
\hline I learnt that leadership is to do jobs more than one at the same time & 1 & - & 1 \\
\hline L I learnt that leadership is to adapt to any kind of environment & 1 & - & 1 \\
\hline I discovered that I have a quality to manage people & 1 & - & 1 \\
\hline I gained a proficiency to make work distribution & 1 & - & 1 \\
\hline I was able to make others work during the activities & 1 & - & 1 \\
\hline If I were a leader, I would try to understand my followers better & 1 & - & 1 \\
\hline I learnt how to behave to the leaders & 1 & - & 1 \\
\hline I had a chance to observe the people taking the lead & 1 & - & 1 \\
\hline I learnt to focus on the solutions instead of the problems & 1 & - & 1 \\
\hline I learnt that leadership is to prepare an effective plan and program & - & 1 & 1 \\
\hline I learnt that leadership means being an emphatatic person & - & 1 & 1 \\
\hline
\end{tabular}

K4 stated her opinion about "I learnt that leadership is directing people without dominating over" which is under the sub-theme of "The effects of service learning and volunteerism activities on students' skills for leadership and their point of view on leadership" as such: "...I was a full of leadeing spirit person. However, I wouldn't like much pressure. I always objected to and defied against it from childhood. But I learnt here how it could be possible without any pressure or dominating over others... but as a leader, you will be on the lead without any dominance, everybody will do their job voluntarily. I actually learnt here how I can direct them and be a friend of theirs." K10 stated his opinion about "I learnt that winning people's trust depends on little details", which belongs to the same sub-theme, as such: "...little things are important. I always give importance to small details. You can hoodwink people with big things, but you can win people with little things. Let me give an example, you come into the room and want to consult about something, for example directly I say "here you are, sit down please", then you yourself start to make a conversation, you might not have started the conversation, you would be a little bit shy, then I would make you relax with the questions... mm, because the thing, well if I spoke standing for example, you wouldn't feel yourself here. Yet, for example you should give people the feeling to be there, I mean the feeling of belonginV. This is possible with little things, .... A smiling face, a welcome, stating that you care about her, acting according to your respondent." 


\section{The effects of service learning and volunteerism activities on students' abilities to carry out a project}

The participants' opinions about the sub-theme of 'The effects of service learning activities on students' abilities to carry out a project' are given in Table 11. As seen in Table 11, of the undergraduate students participating in the study, 3 said "I improved my skills to carry out an organization", 1 said "I saw that the quality of work is important in the organizations" and 1 student said "I saw that the marketing of the work is important in the organizations". The quotations about some of these opinions were given under the table.

Table 11. The effects of service learning and volunteerism activities on students' abilities to carry out a project

\begin{tabular}{|c|c|c|c|}
\hline The effects of service learning and volunteerism activities on students' abilities to carry out a project & $\mathbf{f}$ & & \\
\hline & V. & S.L. & $\mathrm{T}$ \\
\hline I improved my skills to carry out an organization & 1 & 2 & 3 \\
\hline I learnt to work with teamwork & 2 & - & 2 \\
\hline I saw that the quality of work is important in the organizations & 1 & - & 1 \\
\hline I saw that the marketing of the work is important in the organizations & 1 & - & 1 \\
\hline I learnt that timing should be well planned in the organizations & - & 1 & 1 \\
\hline I noticed the importance to see everything together for any kind of organization & 1 & - & 1 \\
\hline I noticed that ther should be someone who controls the job in the organizations & 1 & - & 1 \\
\hline
\end{tabular}

K10 stated his opinions about the statements "I improved my skills to carry out an organization", "I saw that the quality of work is important in the organizations" and "I saw that the marketing of the work is important", which are under the sub-theme of "The effects of service learning and volunteerism activities on students' abilities to carry out a project" as such: "the values added in my business way are organisation and solving problems, we were going to set up a library with 45 people. In some activities, this number goes up to 110 people for example. We would go with 110 people out of the city or here, for example we held some organizations for 1000 or 1500 people... what we mean with the organization is the quality, cleanness I mean a clean job, ... the marketing of the job, well this is about the organisation..." K8 stated his opinion about "I learnt to work with teamwork", which belongs to the same theme, as such: "... this added me value of working as a team and working with higher level teams."

10.4 The Effects of Service Learning and Volunteerism Activities on the Point of View of the Community about Disadvantegous People

In accordance with the $4^{\text {th }}$ purpose of the study, 'The effects of service learning activities on the point of view of the community about disadvantegous people' was determined as the fourth main theme. The participants' opinions about the fourth main theme of the study are given in Table 12. As seen in table 12, of the undergraduate students participating in the study, 1 said "I noticed that we have some deficiencies on the issue of how we, as society, should behave mentally handicapped people" and 1 student said "I started to think that everybody should take education about educating mentally handicapped people". The quotations about some of these opinions were given under the table.

Table 12. The effects of service learning and volunteerism activities on the point of view of the community about disadvantegous people

\begin{tabular}{|c|c|c|c|}
\hline \multicolumn{4}{|l|}{$\begin{array}{l}\text { The effects of service learning and volunteerism activities on the point of view of the } \\
\text { community about disadvantegous people }\end{array}$} \\
\hline & V. & S.L. & $\mathrm{T}$ \\
\hline $\begin{array}{l}\text { I noticed that we have some deficiencies on the issue of how we, as society, should behave } \\
\text { mentally handicapped people }\end{array}$ & - & 1 & 1 \\
\hline $\begin{array}{l}\text { I started to think that everybody should take education about educating mentally } \\
\text { handicapped people }\end{array}$ & - & 1 & 1 \\
\hline I don't see the children with autistm as strangers any more & - & 1 & 1 \\
\hline I saw that how diffifult for some is to get their basic needs & 1 & - & 1 \\
\hline I noticed that I want to help services voluntarily in my future life & 1 & - & 1 \\
\hline I plan to help for needy people in the future & 1 & - & 1 \\
\hline I think to share and use my idea that I want to help in the future with my wife and children & 1 & - & 1 \\
\hline
\end{tabular}

K19 stated his opinion about "I started to think that everybody should take education about educating mentally handicapped people" which is under the sub-theme of "The effects of service learning and volunteerism activities on the point of view of the community about disadvantegous people" as such: "I think not only in higher education but also in all cities these kind of activities need to be organized because the people with autism could be encountered everywhere, not just here. They can be faced outside too and taking extra-education for thi, I mean, I think this education should be taken as compulsorily not selectively by the community because they come to school in general, OK, but you can encounter with these people outside and you can teach them how to act in places, of course they are already taught at school but I mean they will not have teachers with them all the time, their family could be with them, of course the families also teach them but you can add something extra when you see them outside.. not just for individuals with autism, there may be people with down syndrome or mentally handicapped." 


\section{Discussion}

When the category of the acquisitions and awareness about teaching profession, which is under the sub-theme of "the effects of service learning and volunteerism activities on students' knowledge and skills about learning field" are studied, the view "I gained positive acquisitions towards teaching profession" is the highest rated one according to the data obtained. 6 students taking service learning classes and 2 students participating voluntarily in the study stated their opinions to support the statements above during the interviews. The difference between the frequencies could be explained with the fact that service learning class is a teaching practise and thus the participants' opinions taking this lesson are mostly connected with the acquisitions and awareness about teaching profession. According to study Laursen and et.al (2012) made, teachers' views taking service learning classes during undergraduate education also support the idea that the lesson has made an effect on their information and skills about teaching profession in a positive way.

When the category of acquisitions and awareness about teaching profession is studied, which is under the sub-theme of "the effects of service learning and volunteerism activities on students' information and skills about learning fields", it can be observed that the views "My department is faculty of physical education and sport, I noticed I should be quick, practical and careful while working with mentally handicapped students" and "My department is faculty of physical education and sport, I understood if I could teach autistic children, I could teach other children more easily" are included. These views show the acquisitions and awareness of service learning class for P.E students. In Meaney's (2012) study, there are some findings about the knowledge and skills of teachers taking service learning classes have been influenced favourably.

Being under the category of the acquisitions and awareness about teaching profession, the views "service learning class was not sufficiently functional for teaching experience", "service learning class was not functional for the development of students" and "the time planning of service learning class was not appropriate" which belongs to the sub-theme of "the effects of service learning and volunteerism activities on students' information and skills about learning fields" show the participants' critics about the content and planning of service learning classes. In this respect, the effectiveness may have to be reviewed in terms of the students' acquisitions of information and skills about teaching profession of service learning class concerning with teaching practise. According to the findings of the study of Elma and et.al. (2010), teacher candidates reported positive views that the lesson reached its aim, on the other hand they stated that teaching instructors should play less role in determining the institutions to go for practise. In the studies of Reed et.al (2005) and Vernon and Ward (1999) made, it was reported that when the duration is not sufficient enough, service learning class will not be productive.

Being under the category of the acquisitions and awareness about all departments, the views "I experienced the knowledge I learnt in theory" and "I noticed learning by experience is more effective that learning by reading" which belongs to the sub-theme of "the effects of service learning and volunteerism activities on students' information and skills about learning fields" match with the findings in Meaney's (2012) study about the teachers' views showing that those who experienced in teaching in real environments by incorporating in service learning classes during undergraduate education were influenced positively in their careers in the future. which shows that this process. In Cress's (2005) study, findings of similar nature were found. Besides, it could be stated that finding in the study of Astin et.al. (2000) that service learning classes had an effect on the students' academic skills in a positive way had similar properties. Such educational environments allow students to see the reliability of theoretical principles they discussed about in class. The experiences they gained in such environments allow students to make connections with theory and practise and prepare them for their careers.

When the paticipants views, which are under the sub-theme of "the effects of service learning and volunteerism activities on students' career plans, were compared, the opinions "I noticed myself to be a director or something", "I understood that I can make mental handicapped teaching" and "I saw these activities made a difference in my CV" are among the most prominent ones. In the interviews, the undergraduate students not only working voluntarily in the clubs of community services but also taking service learning classes reported that service learning and volunteerism activities had a share in the students' preferences about their career plans. When the studies of Laursen et.al (2012), Newman and Hernandez (2011), Kerrigan (2004) and Astin et.al (2000) were observed, it was seen that service learning courses had positive effects on the students' career developments. In Sax's (1997) study that he made with the undergraduate students involved in voluntary services, it was observed there is a finding that volunteering has a positive effect on students' career planninV.

One of the undergraduate students working voluntarily for a community service stated that "I noticed that I wanted to work in the fields such as trading or politics" which is under the sub-theme of "the effects of service learning and volunteerism activities on students' career plans". When studied of Winston's (2015), Kiely's (2004) and Fenzel and Peyrot's (2005) researches, it was recognized that the students' behaviours into politics were influenced with certain 
aspects such as political involvement, being interested in political issues, changing of political view and being effective in provision of social change. In Kerrigan's (2004) study, only one third of the participants reported that they improved their characteristics in making connections with social issues concerning with politics. The finding explored in this study is that students' wishing to be in a position to make politics is connected with their involvement in service learning and volunteerism activities. The student mentioned carry out the responsibilities of presidency in a service organization serving for the community.

Being under the sub-theme of "the effects of social learning activites on the students'personal characteristics", the opinions "My self-confidence increased, My joy of living increased, I learnt not to give up, My empathy increased, I became a more blessing person, I became a more responsible person, I became a more hardworking person, I knew more about myself, I became a more patient person, I felt proud of myself, I felt myself respected and I noticed I am a patient person" were the most prominent ones among the participants. In the researches of Laursen et.al. (2012), Sönmez (2010), Elma et.al. (2010), Çetin and Sönmez (2009), Kiely (2004), Sedlak (2003), and Astin et.al. (2000), Peterson (1998), there are some findings that service learning classes have positive effect on the students' personal developments, self-confidence, self respect and the perception of self proficieny. In the study of Sax (1997) he made with the students incorporating in voluntary activities, there are some findings that volunteering has positive effect on the undergraduate students' self-confidence. In Primavera's (1999)' study he made with the undergraduate students in voluntary services, it was determined that volunteering has improved students in some issues such as knowing himself, personal growth, personal effectiveness, improving in academic and social awareness. These findings match up with the views included in the sub-theme "the effects of social learning activites on the students'personal characteristics". The views in the sub-theme of "the effects of social learning activities on the students'personal characteristics" belong mostly to the undergraduate students working in voluntary services serving for the community. This situation can result from the fact that community services show more variety, when compared with content of the lesson, than service learning classes.

In the study of Laursen et.al. (2012) which he made with the students taking service learning classes, the students reported that helping others gave them an internal pleasure and this view matches up with the ones, "I became happy" and "I felt spiritual satisfaction" which are under sub-theme of "the effects of service learning and volunteerism activities on students' emotions".

The views "My ability to solve problems improved", "My ability to think in multiple ways improved", "My ability to think creatively improved" and "my ability to think strategically improved" which are under the sub-theme of "the effects of service learning and volunteerism activities on students' cognitive skills" are among the most prominent ones the participants used. The activities develop and strengthen the students' writing skills, critical and profound thinking skills and questioninV. The views under the sub-theme of "the effects of service learning and volunteerism activities on students' cognitive skills" can be assessed in terms of the students' academic and intellectual development. In their studies about the effects of service learning classes on students, Sönmez (2010), Kiely (2004), Sedlak (2003), Astin et.al (2000) obtained the findings that the classes had positive effect on the students' writing skills, critical thinking skills, intellectual development and academic skills. In the study of Cress (2005) there are some views that such lessons contribute to the students' academic and critical thinkinV. In the studies of Sax (1997) and Astin (1996) it was proved that the academic success of the students participating in voluntary services were higher than non-participant stduentsn and these students generally study even in their spare times, also there some findings that the lessons had a positive effect on the students' critical thinking skills. The views under the sub-theme of "the effects of service learning and volunteerism activities on students' cognitive skills" belong mostly to undergraduate students taking service learning classes.

The view "I noticed that anyone can do any job" belonging to the sub-theme of "The effects of service learning and volunteerism activities on students' relations with people and their point of view about people" can match with the view "having such experiences for candidate teachers leads them to believe a faith that all students could make it by developing a strong sense of self-respect" in Meaney's study (2012). The view "my prejudices were broken down" which is under the sub-theme of "The effects of service learning and volunteerism activities on students' relations with people and their point of view about people" can be thought to have similarities to the view that "service learning classes facilitate the students' acceptance of different cultures" in Meaney's (2012) study, and the view that "service learning classes facilitate students' acceptance of different communities coming from different socio-economy, ethnic identity or regions with different skills" in Kerrigan's (2004) study. However, in Crandall's and Zachary's (2013) study, it couldn't be found any important evidence that service learning classes contribute students to be open to differences. Moreover, the view "my prejudices were broken down" can be thought to be at the same level with the view that service learning classes serve for promoting racial understanding in the study of Astin et.al (2000). In the study of Driscoll et.al. (1996), there are some findings that service learning has some positive contibutions on the students' relationship with 
people. The view "my prejudices were broken down" matches with the view that "voluntary services influence the students on the acceptance and recognition of different cultures in a positive way" in Primavera's (1999) and Sax's (1997) studies. The same view can be considered to be at the same level with the view that voluntary service activities serve positively for students' racial understanding

The participants' opinions which is under the sub-theme of "The effects of service learning and volunteerism activities on students' communication skills" show that service learning and volunteerism activities contribute on the communication skills of the students in a favourable way; relevant opinions were given rather by the students who took place in service activites voluntarily. In the studies of Newman and Hernandez (2011), Elma et.al (2010), Sönmez (2010), Çetin and Sönmez (2009), Quezada and Christopherson (2005), Vogelgesang and Astin (2000) about the effects of service learning classes on undergraduate students, there are some findings that the lesson had positive effects on students' communication skills.

The views "I learnt that leadership is directing people without dominating over", "I noticed the importance of being open-minded instead of saying "I know", "I learnt that leadership is to manage people" and "I learnt that winning people's trust depends on little details" which belong to the sub-theme of "The effects of service learning and volunteerism activities on students' leadership skills and their point of view towards leadership are the prominent opinions. In the studies of Newman and Hernandez (2011), Elma et.al (2010), Quezada and Christopherson (2005), Astin et.al. (2000), Vogelgesang and Astin (2000) about the effects of service learning classes on undergraduate students, there are some findings that the lesson had positive effects on the students' leadership skills. In Sax's (1997), Astin's (1996) studies, made with the students having participated in voluntary service activities during higher education, there are some findings that volunteering had positive effects on the students' leadershşip skills. The views towards the effects of service activities on students' leadership skills were given rather by the students who participate in the activities voluntarily. The students participating in the study and involved in the voluntary activities not just made presidency of their clubs but the activites they were involved in varied also and this situation could be the reason why they spoke about leadership more than the ones taking service learning classes.

The view "I learnt to work with a team" which is under the sub-theme of "the effects of service learning and volunteerism activities on students' abilities to carry out a project" shows the positive effects of the ability to carry out a project on the participants; relevant opinions were given by the students who work for service activities voluntarily. In the studies of Newman and Hernandez (2011), and Çetin and Sönmez (2009) about the effects of service learning and volunteerism activities on undergraduate students, there are some findings that the lesson had positive effects on the students' teamwork skills. The opinions under this sub-theme are such as to support Kerrigan's (2004) view that the lesson supports some academic skills such as carrying out long term projets. In Sax's (1997) study which he made with undergraduate students incorporating in voluntary activities, there are some opinions that volunteering had some favourable effects on the students' abilities of teamwork.

The views under the sub-theme of "The effects of service learning and volunteerism activities on the point of view of the community about disadvantegous people" report the participants' sensitivities to social problems and it also shows that they will involve in community service activities in the future. In the studies of Newman and Hernandez (2011), Sönmez (2010), Elma et.al (2010), Çetin and Sönmez (2009), Astin et.al. (2006), Fenzel and Peyrot (2005), Kerrigan (2004), Sedlak (2003) and Astin et.al. (2000), Antonio et.al. (2000), there are some findings that the students taking service learning classes took place or wished to take place in voluntary service activities and they gave importance to prosocial behaviours. This situation can serve for social justice to develop in the society. In the studies of Primavera (1999), Sax (1997), and Astin (1996) which they made with the students participating in voluntary activities during higher education, there are some findings that volunteering had a positive effect on students.

The views under the sub-theme of "the reasons of the students' participation in service learning and volunteerism activities" couldn't be found in the findings of the studies, which were analysed by the researcher. 


\section{Results and Suggestions}

Consequently, in this study, 4 main themes, 9 sub-themes and 3 categories were detected in accordance with the purposes of the study. These are classified as follows:

\begin{tabular}{|c|c|c|c|c|c|c|c|c|c|c|c|c|}
\hline \multirow{3}{*}{$\begin{array}{l}\text { 1.The reasons } \\
\text { of the } \\
\text { participation }\end{array}$} & \multicolumn{4}{|c|}{ 2.Career developments } & \multicolumn{7}{|c|}{ 3.Personal developments } & \multirow{3}{*}{ 4.Disadvantageous } \\
\hline & \multicolumn{3}{|c|}{$\begin{array}{l}\text { a. Information and } \\
\text { skills }\end{array}$} & \multirow[t]{2}{*}{$\begin{array}{l}\text { b. Career } \\
\text { plans }\end{array}$} & \multirow[b]{2}{*}{ 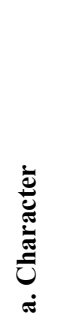 } & \multirow[b]{2}{*}{ 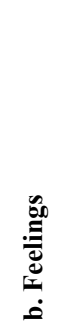 } & \multirow[b]{2}{*}{ 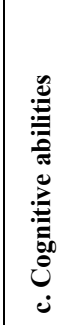 } & \multirow{2}{*}{ 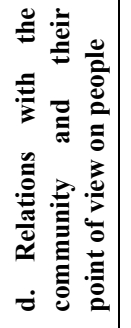 } & \multirow[b]{2}{*}{ 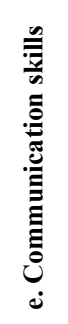 } & \multirow[b]{2}{*}{ 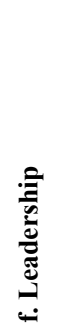 } & \multirow[b]{2}{*}{ 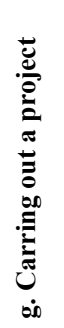 } & \\
\hline & 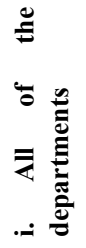 & 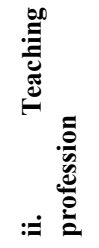 & 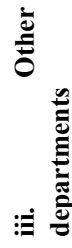 & & & & & & & & & \\
\hline
\end{tabular}

Based on the results of the study, the suggestions determined for practitioners:

- Some works can be done so that service leaning classes and voluntary service works could be made widespread.

- The collaboration between higher education institutions and NGOs can be increased more.

- The practising process and planning of service learning classes can be made more effective

- The participation of the students into voluntary service activities during higher education can be promoted.

Based on the results of the study, the suggestions determined for researchers:

- Some studies could be performed about the approaches into social problems after graduation of the students who took service learning classes or participated in voluntary service activities during higher education

- Some studies could be performed about the point of views on the issues such as prosocial behaviours, patriotism, political involvement and political socialization of the graduate or undergraduate students who took service-learning classes or took part in voluntary service activities during higher education.

Appendix - 1

\section{DEMOGRAPHIC FEATURES}

1. Sex () Woman () Man

2. Age

3. Class

4. Department

\section{Questions}

1. Why did you participate in service learning and volunteerism activities?

2. How have service learning and volunteerism activities affect on your career developments?

a. How have service learning and volunteerism activities affected on your information and skills about your learning fields?

b. How have service learning and volunteerism activities affected on your information and skills about your career planning?

3. How have service learning and volunteerism activities affected on your personal development?

a. How have service learning and volunteerism activities affected on their personal characteristics?

b. How have service learning and volunteerism activities affected on their feelings?

c. How have service learning and volunteerism activities affected on their cognitive abilities?

d. How have service learning and volunteerism activities affected on their relations with community and their point of view on people? 
e. How have service learning and volunteerism activities affected on their communication skills?

f. How have service learning and volunteerism activities affected on their qualities for leadership and their point of view on leadership?

g. How have service learning and volunteerism activities affected on their ability to carry out a project?

4. How have service learning and volunteerism activities affected on their point of view on disadvantageous people?

\section{References}

Antonio, A. L., Astin, H. S., \& Cress, C. H. (2000). Community service in higher education: A look at the nation's faculty. Review of Higher Education, 23(4), 373-397. https://doi.org/10.1353/rhe.2000.0015

Astin, A. W. (1993). What matters in college?: Four critical years revisited (Vol. 1). San Francisco: Jossey-Bass.

Astin, A. W. (1996). The role of service in higher education. About Campus, 1(1), 14-110. https://doi.org/10.1002/abc.6190010104

Astin, A. W., Vogelgesang, L. J., Ikeda, E. K., \& Yee, J. A. (2000). How service learning affects students. Los Angeles, CA: Higher Education Research Institute, University of California, Los Angeles.

Astin, A. W., Vogelgesang, L. J., Misa, K., Anderson, J., Denson, N., Jayakumar, U., \& Yamamura, E. (2006). Understanding the efects of service-learning: A study of students and faculty. Los Angeles, CA: Higher Education Research Institute, University of California, Los Angeles.

Bandura, A. (1978). The self system in reciprocal determinism. American psychologist, 33(4), 344. https://doi.org/10.1037/0003-066X.33.4.344

Boyer, E. L. (1987). College: The undergraduate experience. America, 110.

Çetin, T., \& Sönmez, Ö. F. (2009). Sosyal bilgiler öğretmen adaylarının topluma hizmet uygulamaları dersinin amaç ve içeriğine yönelik görüşlerinin değerlendirilmesi. Gazi Üniversitesi Gazi Eğitim Fakültesi Dergisi, 29(3).

Crandall, J., \& Zachary, C. (2013). The Efficacy of Service-Learning in Health Education to Increase Pre-Service Teachers' Openness to Diversity. Kentucky Association of Health, Physical Education, Recreation and Dance, 18.

Cress, C. M. (2005). What is service-learning? In C. M. Cress, P. J. Collier, V.L. Reitenauer (eds.) Learning Through Serving: A Student Guidebook for Service-Learning Across Disciplines. Sterling, VA: Stylus.

Dewey, J. (1916). Democracy and education: An introduction to the philosophy of education. New York, NY: Macmillan.

Dovidio, J. F., Piliavin, J. A., Schroeder, D. A., \& Penner, L. A. (2006). The social psychology ofprosocial behavior. Mahwah, N.J.: Lawrence Erlbaum Publishers.

Drezner, N. (2011). What Guides the Study of Philanthropy and Fundraisin V. ASHE higher education report: Special issue: Philanthropy and Fundraising in American Higher Education, 37(2), 47-63.

Driscoll, A., Holland, B., Gelmon, S., \& Kerrigan, S. (1996). An assessment model for service-learning: Comprehensive case studies of impact on faculty, students, community, and institutions. Michigan Journal of Community Service Learning, 3, 66-71.

Eisenberg, N., \& Fabes, R. A. (1991). Prosocial behavior and empathy: a multimethod devel- opmental perspective. See Clark 1991, 34-61.

Elma, C., Kesten, A., Kıroğlu, K., Uzun, E. M., \& Dicle, A. N. (2010). Öğretmen adaylarının topluma hizmet uygulamaları dersine ilişkin algıları. Kuram ve Uygulamada Egitim Yönetimi Dergisi, 16(2), 231-252.

Eyler, J. (2002). Reflection: Linking service and learning — Linking students and communities. Journal of Social Issues, 58(3), 517-534. https://doi.org/10.1111/1540-4560.00274

Eyler, J., \& Giles, D. E. Jr. (1999). Where's the learning in service-learning? San Francisco: Jossey- Bass.

Fenzel, L. M., \& Peyrot, M. (2005). Comparing college community participation and future service behaviors and attitudes. Michigan Journal of Community Service Learning, 12(1), 23-31.

Flecky, K., \& Gitlow, L. (2010). Service-learning in occupational therapy education. Jones \& Bartlett Publishers.

Hall, D., Hall, I., Cameron, A., \& Green, P. (2004). Student volunteering and the active community: Issues and opportunities for teaching and learning in sociology. Learning and Teaching in the Social Sciences, 1(1), 33-50. https://doi.org/10.1386/ltss.1.1.33/0

Huberman, A. M., \& Miles, M. B. (1994). Data management and analysis methods. 
Hurvitz, L. A. (2010). Building a culture of student philanthropy: A study of the Ivy-Plus institutions' philanthropy education initiatives.

Kerrigan, S. M. (2004). Perspectives of college graduates on the experience and e ect of Capstone service-learning courses: A qualitative study (Doctoral dissertation, AAT 3169484). Retrieved from http://www.pdx.edu/ education/gse-doctoral-dissertations

Kiely, R. (2004). A chameleon with a complex: Searching for transformation in international service learninV. Michigan Journal of Community Service Learning, 10(2), 5-20.

Lake, V. E., Winterbottom, C., Ethridge, E. A., \& Kelly, L. (2015). Reconceptualizing Teacher Education Programs: Applying Dewey's Theories to Service-Learning with Early Childhood Preservice Teachers. Journal of Higher Education Outreach and Engagement, 19(2), 93-116.

Laursen, S. L., Iry, H., \& Liston, C. S. (2012). e impact of a university- based school science outreach program on graduate student participants' career paths and professional socialization. Journal of Higher Education Outreach \& Engagement, 16(2), 47-78.

Lenzi, M., Vieno, A., Perkins, D. D., Santinello, M., Elgar, F., Morgan, A., \& Mazzardis, S. (2012). Family affluence, school and neighborhood contexts and adolescents' civic engagement: A cross-national study. American Journal of Community Psychology, 50, 197- 210. https://doi.org/10.1007/s10464-012-9489-7

Meaney, K. S., Housman, J., Cavazos, A., \& Wilcox, M. L. (2012). Examining Service-Learning in a Graduate Physical Education Teacher Education Course. Journal of the Scholarship of Teaching and Learning, 12(3), 108-124.

Mitchell, T. D. (2008). Traditional vs. critical service-learning: Engaging the literature to differentiate two models. Michigan Journal of Community Service Learning, 14(2).

Mulugetta, Y., Nash, S., \& Murphy, S. H. (1999). What makes a difference: Evaluating the Cornell tradition program. New Directions for Institutional Research, 1999(101), 61-80. https://doi.org/10.1002/ir.10104

National Commission on Service-Learning, 2002. http://ed253jcu.pbworks.com/f/LearningDeedServiceLearning_American+Schools.PDF

Newman, C. M., \& Hernandez, S. Q. (2011). Minding our business: Longitudinal e ects of a service learning experience on alumni. Journal of College Teaching \& Learning, 8(8), 39-48. https://doi.org/10.19030/tlc.v8i8.5321

O'Dwyer, C., \& Timonen, V. (2009). Doomed to extinction? The nature and future of volunteering for meals-on-wheels services. Voluntas, 20(1), 35-410. https://doi.org/10.1007/s11266-008-9074-8

Pancer, S., \& Pratt, M. (1999). Social and family determinants of community service involvement in Canadian youth. In M. Yates \& J. Youniss (Eds.), Roots of civic identity (pp. 32-55).New York, NY: Cambridge University Press.

Penner, L. A., Dovidio, J. F., Piliavin, J. A., \& Schroeder, D. A. (2005). Prosocial behavior: Multilevel perspectives. Annu. Rev. Psychol., 56. https://doi.org/10.1146/annurev.psych.56.091103.070141

Peterson, E. A. (1998). What can adults learn from community service? Lessons learned from Americorps. Community Education Journal, 25(1-2), 45-46, 365-392. https://doi.org/10.1146/annurev.psych.56.091103.070141

Primavera, J. (1999). The unintended consequences of volunteerism: Positive outcomes for those who serve. Journal of Prevention \& Intervention in the Community, 18(1-2), 125-140. https://doi.org/10.1300/J005v18n01_10

Quezada, R. L. \& Christopherson, R. W. (2005). Adventure-based service learning: University students' self-reflection accounts of service with children. Journal of Experiential Education, 28(1), 1-16. https://doi.org/10.1177/105382590502800103

Reed, V. A., Jernstedt, V. C., Hawley, J. K., Reber, E. S., \& DuBois, C. A. (2005). Effects of a small-scale, very short-term service-learning experience on college students. Journal of Adolescence, 28(3), 359-368. https://doi.org/10.1016/j.adolescence.2004.08.003

Ryan, R., Kaplan, R., \& Grese, R. (2001). Predicting volunteer commitment in environmental stewardship programmes. Journal of Environmental Planning and Management, 44(5), 629-648. https://doi.org/10.1080/09640560120079948

Salamon, L. M. (1992). America's nonprofit sector: A primer. New York: Foundation Center.

Sax, L. (1997). The benefits of service: Evidence from undergraduates. Educational record, 25.

Schervish, P. (1998). Philanthropy. In R. Wuthnow (ed.), Encyclopedia of politics and religions (pp. 600-603). Washington, DC: Congressional Quarterly. 
Sedlak, C. A., Doheny, M. O., Panthofer, N., \& Anaya, E. (2003). Critical thinking in students' service-learning experiences. College Teaching, 51(3), 99-104. https://doi.org/10.1080/87567550309596420

Sönmez, Ö. F. (2010). Sosyal bilgiler öğretmen adaylarının topluma hizmet uygulamaları dersine yönelik görüşlerinin kazanım boyutunda değerlendirilmesi. Karadeniz Sosyal Bilimler Dergisi, 2(2), 53-72.

Sulek, M. (2010). On the modern meaning of philanthropy. Nonprofit and voluntary sector quarterly, 39(2), 193-212. https://doi.org/10.1177/0899764009333052

Van Til, J. (1990). Critical issues in American philanthropy: Strengthening theory and practice. Glenview. IL: AAFRC Trust for Philanthropy.

Vernon, A., \& Foster, L. (2002). Nonprofit agency perspectives of higher education service learning and volunteerism. Journal of Nonprofit \& Public Sector Marketing, 10(2), 207-230. https://doi.org/10.1300/J054v10n02_12

Vernon, A., \& Ward, K. (1999). Campus and community partnerships: Assessing impacts and strengthening connections. Michigan Journal of Community Service Learning, 6, 30-37.

Vogelgesang, L. J., \& Astin, A. W. (2000). Comparing the Effects of Service- Learning and Community Service. Michigan Journal of Community Service Learning, 7, 25-34.

Winston, F. (2015). Reflections upon community engagement: Service-learning and its effect on political participation after college. Journal of Higher Education Outreach and Engagement, 19(1), 79-104.

\section{Copyrights}

Copyright for this article is retained by the author(s), with first publication rights granted to the journal.

This is an open-access article distributed under the terms and conditions of the Creative Commons Attribution license which permits unrestricted use, distribution, and reproduction in any medium, provided the original work is properly cited. 